\title{
The first Saudi baby with classic homocystinuria diagnosed by universal newborn screening
}

Talal AlAnzi, MD, Fahad J. Al Harbi, PhD, Joharah AlFaif, MSc, Sarar Mohamed, FRCPCH, MD.

\begin{abstract}

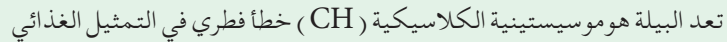

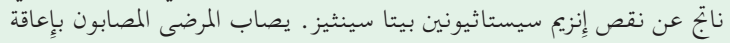

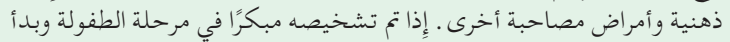

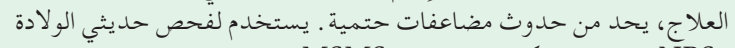

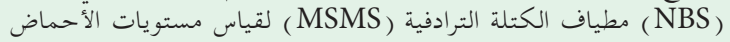

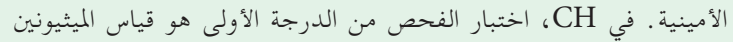

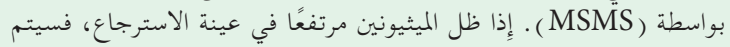

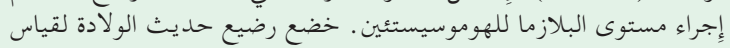
(NBS)

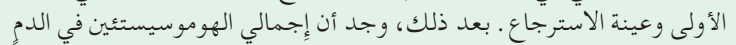

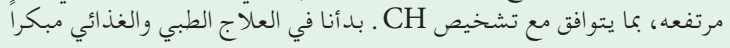

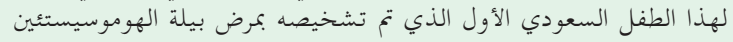

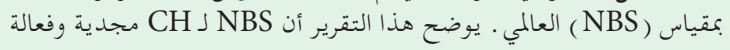

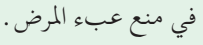

Classic homocystinuria $(\mathrm{CH})$ is an inborn error of metabolism caused by cystathionine beta-synthase enzyme deficiency. Affected patients present with intellectual disability and other comorbidities. If diagnosed early in infancy and started treatment, inevitable complications can be prevented. Newborn screening (NBS) uses tandem mass-spectroscopy (MSMS) to measure the amino acid levels. In $\mathrm{CH}$, the first-tier screening test is the measurement of methionine by MSMS. If methionine remained elevated in the recall sample, plasma level for homocysteine is performed. A newborn infant underwent routine NBS in our institute that showed elevated methionine in the first and the recall sample. Thereafter, total serum homocysteine was found to be elevated, consistent with the diagnosis of $\mathrm{CH}$. An early medical and dietary management was commenced for this first Saudi baby diagnosed with homocystinuria by universal NBS. This report demonstrates that NBS for $\mathrm{CH}$ is feasible and effective in preventing the disease burden.

Keywords: CBS gene, homocystinuria, newborn, screening

Saudi Med J 2021; Vol. 42 (2): 219-222 doi: 10.15537/smj.2021.2.25643
From the Department of Pediatrics (AlAnzi, Mohamed); from the Department of Biochemical laboratory (Al Harbi, AlFaifi), Prince Sultan Military Medical City; from the Prince Abdullah bin Khalid Celiac Disease Research Chair (Mohamed), King Saud University; and from the Department of Pediatrics (Mohamed), College of Medicine, AlFaisal University, Riyadh, Kingdom of Saudi Arabia.

Received 17th November 2020. Accepted 10th December 2020.

Address correspondence and reprint request to: Dr. Talal AlAnzi, Department of Pediatrics, Prince Sultan Military Medical City, Riyadh, Kingdom of Saudi Arabia.E-mail: talanzi@psmmc.med.sa ORCID ID: http://orcid.org/0000-0003-315-6759

$\mathrm{C}$ lassic homocystinuria $(\mathrm{CH})$ is an inborn error of metabolism of sulfur amino acid, which is caused by cystathionine beta-synthase (CBS) deficiency (MIM\#236200). Cystathionine beta-synthase enzyme catalyzes the first step of the transsulfuration pathway. Its deficiency results in elevated serum homocysteine and methionine. Classic homocystinuria is caused by different variants in the CBS gene. ${ }^{1}$ Some patients present in childhood with multisystem disease, whereas others are asymptomatic into adulthood. The major clinical features are dislocation of the optic lenses, osteoporosis, 'marfanoid' habitus, learning difficulties, and thromboembolic events. ${ }^{2}$ Patients diagnosed by newborn screening (NBS) do not exhibit the clinical manifestations of the disease at birth. Moreover, early diagnosis and treatment have been shown to prevent the complications of $\mathrm{CH}$, including developmental delay. ${ }^{3}$ The primary treatment strategy for $\mathrm{CH}$ is the introduction of a low methionine diet. Another therapeutic intervention is betaine therapy, which utilizes alternative pathways to reduce serum homocysteine. Increasing residual enzyme activity is entertained by using pyridoxine in patients with vitamin responsive

Disclosure. Authors have no conflict of interests, and the work was not supported or funded by any drug company. 
variants. ${ }^{4}$ Newborn screening for inherited metabolic disorders aims to detect patients before the symptoms and signs of diseases appear. The national NBS program in Saudi Arabia started in 2005. Currently, this program screens for 16 disorders, including different inborn errors of metabolism, congenital hypothyroidism, and congenital adrenal hyperplasia. Classic homocystinuria is not yet included in the national NBS program in Saudi Arabia. Nevertheless, the NBS in Prince Sultan Military Medical City (PSMMC) added $\mathrm{CH}$ to the existing disorders panel. ${ }^{5}$ The prevalence of $\mathrm{CH}$ in Saudi Arabia is unknown. However, like other autosomal recessive metabolic disorders, $\mathrm{CH}$ is predicted to be prevalent in the consanguineous Saudi population. ${ }^{6}$

In this report, we describe the first Saudi patient with $\mathrm{CH}$, who was diagnosed by universal NBS.

Case Report. Clinical information. The proband is a baby boy born at term with normal vaginal delivery weighing $3.5 \mathrm{~kg}$, within the 50th centile chart. His clinical examination was unremarkable, including normal facial appearance, eyes, and central nervous

Table 1 - Biochemical and genetic characteristics of the patient with classic homocystinuria.

\begin{tabular}{lcc}
\hline Test & Result & $\begin{array}{c}\text { Reference } \\
\text { range }\end{array}$ \\
\hline Methionine (first sample) & 119 & $\begin{array}{c}8-75 \\
\text { micromol/L }\end{array}$ \\
Methionine (recall sample) & 146 & $\begin{array}{c}8-75 \\
\text { micromol/L } \\
\text { Less than 1 }\end{array}$ \\
$\begin{array}{l}\text { Methionine/Phenylalanine ratio } \\
\text { (first sample) }\end{array}$ & 1 & Less than 1 \\
$\begin{array}{l}\text { Methionine/Phenylalanine ratio } \\
\text { (recall sample) }\end{array}$ & 1.9 & $\begin{array}{c}\text { Less than 10 } \\
\text { Serum Homocysteine }\end{array}$ \\
$\begin{array}{l}\text { Molecular analysis } \\
\text { micromol/liter } \\
\text { a homozygous pathogenic variant } \\
\text { of cystathionine beta-synthase } \\
\text { gene c.969G }>\text { A p.(Trp323*) }\end{array}$ \\
\hline
\end{tabular}

system examination. The baby was commenced on bottle feeding. His parents are first cousins and have no family history of a genetic disease.

Diagnostic assessment. Newborn screening test was performed by taking a blood sample from his heel and analyzed by tandem mass spectroscopy (MSMS). The first NBS sample showed high methionine level $119 \mathrm{umol} / \mathrm{l}$ (normal: 8-75 umol/l) with methionine/ phenylalanine ratio of 1 (normal is less than 1) (Table 1 ). The recall NBS sample showed higher methionine level, $146 \mathrm{umol}$, and higher ratio 1.9 consistent with possible $\mathrm{CH}$. Then, his total plasma homocysteine was measured and found high at $204.4 \mathrm{umol} / \mathrm{l}$ (normal less than $10 \mathrm{umol} / \mathrm{l}$ ), confirming the diagnosis of $\mathrm{CH}$. The family was counseled regarding the diagnosis, the management plan, the prognosis, and the recurrence risk.

Therapeutic intervention. The baby was managed according to the $\mathrm{CH}$ guidelines that include starting low homocysteine special formula with restriction of natural protein intake. The medical treatment prescribed was intramuscular hydroxocobalamin injection $1 \mathrm{mg}$ weekly, oral folic acid $2.5 \mathrm{mg}$ daily, betaine 0.5 gram daily (dosage $100-150 \mathrm{mg} / \mathrm{kg} /$ day), and pyridoxine $40 \mathrm{mg}$ twice a day. After one month of therapy, the total homocysteine was $1.50 \mathrm{umol} / \mathrm{l}$ (normal less than $10 \mathrm{umol} / \mathrm{l})$. Timeflow was shown in Table 2.

Follow up and outcome. Whole exome sequencing revealed a homozygous pathogenic variant of CBS gene c. $969 \mathrm{G}>\mathrm{A}$ p. $\left(\operatorname{Trp} 323^{*}\right)$ that confirmed the diagnosis of $\mathrm{CH}$ at the molecular level (Figure 1). The baby was followed up by the medical and the dietetic team for one year. His growth and development were age-appropriate. His physical and eye examination was normal.

Discussion. In this report, we present the first baby with classic homocystinuria diagnosed on routine newborn screening in Saudi Arabia. The national NBS program in Saudi Arabia started in 2005, with 15 disorders in the screening panel. These disorders include aminoacidopathies, organic aciduria, fatty acid

Table 2 - Timeline of the studied participant.

\begin{tabular}{llll}
\hline Event date & Clinical presentation & Diagnostic findings & Outcome and intervention \\
\hline 4 June 2019 & Birth, asymptomatic & NBS, universal sample & High methionine, high homocystine to repeat NBS \\
8 June 2019 & 4 day old, asymptomatic & NBS recall & High methionine, high homocystine \\
8 June 2019 & 4 day old, asymptomatic & Dx: homocystinuria & Started on therapy and metabolic formula \\
16 July 2019 & 6 week old, asymptomatic & Whole exome sequencing & CBS mutation \\
\hline \multicolumn{2}{c}{ NBS - newborn screening, CBS: cystathionine beta-synthase } \\
\hline
\end{tabular}




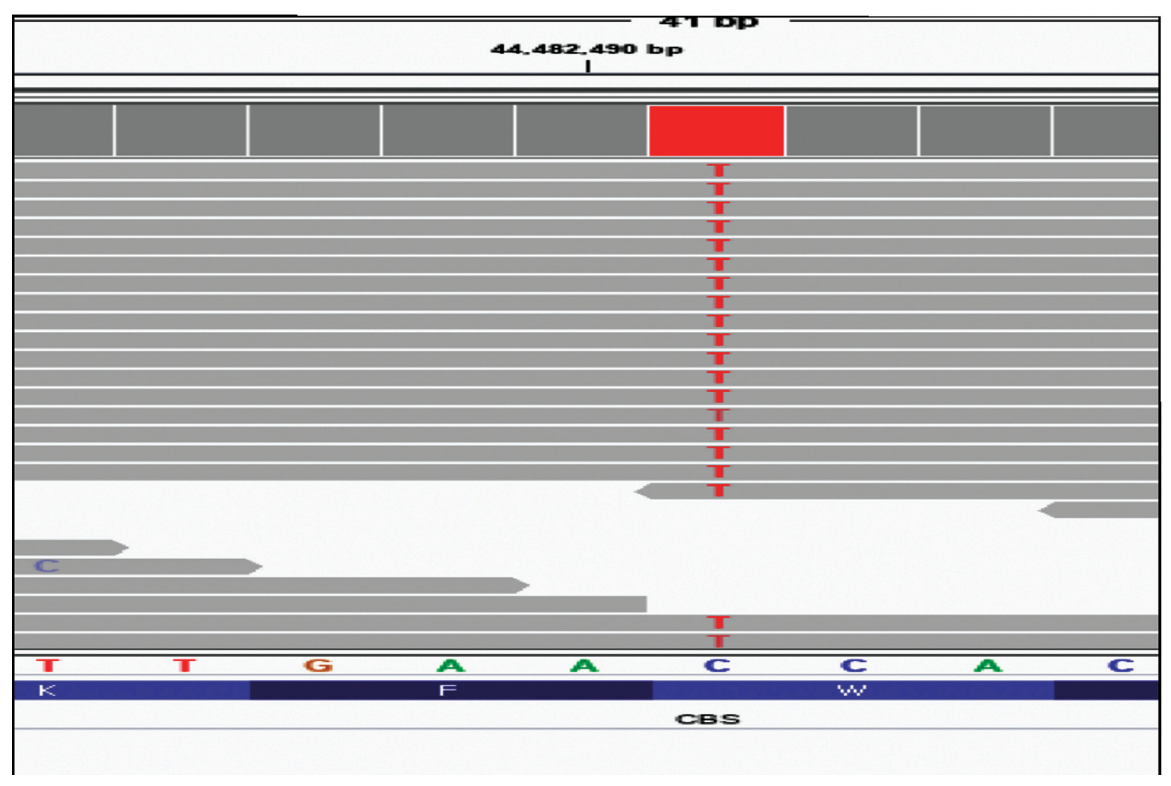

Figure 1 - Chromatograph of cystathionine beta-synthase gene showing a homozygous pathogenic variant.

oxidation defects, and 2 endocrine disorders, namely, congenital hypothyroidism, and congenital adrenal hyperplasia. ${ }^{7}$ However, $\mathrm{CH}$ is not included in the national NBS program. The overall incidence of the screened diseases covered by the national NBS in Saudi Arabia between 2005 and 2012 was 1:1043, one of the highest incidence reported worldwide. ${ }^{6}$ The incidence of IEM is higher than that observed globally which is to 50.9 per 100000 live births. ${ }^{7}$ This high incidence of genetic diseases in Saudi Arabia is caused by the high rate of consanguineous marriages in this country, which was estimated between $58 \% .^{8}$ The patient reported in this study was born in Prince Sultan Military Medical City (PSMMC), a tertiary-level facility that serves the military personnel and their families. Our institute screens for the 17 disorders covered by the national NBS program; however, from January 2019, 3 diseases were added to the screening panel. These are $\mathrm{CH}$, tyrosinemia, and primary carnitine deficiency. ${ }^{5}$ Our patient was the first baby diagnosed by routine NBS since the introduction of $\mathrm{CH}$ screening in our hospital. Up to our knowledge, no other health care facility in Saudi Arabia currently screen for $\mathrm{CH}$.

Most of the patients with $\mathrm{CH}$ in Saudi Arabia are diagnosed late. Zaidi et $\mathrm{al}^{9}$ demonstrated this in 2011, who reported a case series of Saudi and Sudanese patients with $\mathrm{CH}$ who were diagnosed late and, therefore, mostly presented with complications including developmental delay, thromboembolism, skeletal deformity, and ectopia lentis. ${ }^{9}$ Individuals with
$\mathrm{CH}$ who were diagnosed in early infancy by NBS are expected to attain normal or nearly normal growth and development. Gan-Schreier et $\mathrm{al}^{10}$ reported that over 3 years, a total of 14 patients with $\mathrm{CH}$ were diagnosed by NBS in Qatar; all had normal growth and development. This demonstrates that NBS for homocystinuria is feasible and effective. It prevents developmental delay, skeletal, and eye complications associated with $\mathrm{CH}$.

In conclusion, we report the first baby diagnosed with $\mathrm{CH}$ by routine NBS. Including $\mathrm{CH}$ in the screened panel in the Saudi NBS is recommended to prevent the devastating disease burden associate with the late diagnosis of $\mathrm{CH}$.

\section{References}

1. Morris AA, Kožich V, Santra S, Andria G, Ben-Omran TI, Chakrapani AB, et al. Guidelines for the diagnosis and management of cystathionine beta-synthase deficiency. J Inherit Metab Dis 2017; 40: 49-74.

2. Moretti R, Caruso P. The controversial role of homocysteine in neurology: from labs to clinical practice. Int J Mol Sci 2019; 20: 231.

3 Voskoboeva E, Semyachkina A, Yablonskaya M, Nikolaeva E. Homocystinuria due to cystathionine beta-synthase (CBS) deficiency in Russia: Molecular and clinical characterization. Mol Genet Metab Rep 2017; 14: 47-54.

4. Kumar T, Sharma GS, Singh LR. Homocystinuria: Therapeutic approach. Clin Chim Acta 2016; 458: 55-62.

5. Mohamed S, Elsheikh W, Al-Aqeel AI, Alhashem AM, Alodaib A, Alahaideb L, et al. Incidence of newborn screening disorders among 56632 infants in Central Saudi Arabia. A 6-year study. Saudi Med J 2020; 41: 703-708. 
6. Alfadhel M, Al Othaim A, Al Saif S, Al Mutairi F, Alsayed M, Rahbeeni Z, et al. Expanded newborn screening program in Saudi Arabia: Incidence of screened disorders. J Paediatr Child Health 2017; 53: 585-591.

7. Walter D, Adeloye D, Woolham D, Westnedge E, Patel S, Rudan I. Global birth prevalence and mortality from inborn errors of metabolism: a systematic analysis of the evidence. $J$ Glob Health 2018; 8: 021102.

8. Bener A, Mohammad R. Global distribution of consanguinity and their impact on complex diseases: Genetic disorders from an endogamous population. Egypt J Med Hum Genet 2017; 18 : 315-320.
9. Zaidi SH, Faiyaz-Ul-Haque M, Shuaib T, Balobaid A, Rahbeeni $\mathrm{Z}$, Abalkhail $\mathrm{H}$, et al. Clinical and molecular findings of 13 families from Saudi Arabia and a family from Sudan with homocystinuria. Clin Genet 2012; 81: 563-570.

10. Gan-Schreier H, Kebbewar M, Fang-Hoffmann J, Wilrich J, Abdoh G, Ben-Omran T, et al. Newborn population screening for classic homocystinuria by determination of total homocysteine from Guthrie cards. J Pediatr 2010; 156: 427-432. 